\title{
PEMBELAJARAN BERBASIS MASALAH UNTUK MENINGKATKAN KEMAMPUAN PEMECAHAN MASALAH MATEMATIS SISWA SMK
}

\author{
Eva Tri Wahyuni \\ STKIP Sebelas April Sumedang \\ evatriwahyuni88@yahoo.co.id
}

\begin{abstract}
Abstrak : Penelitian ini berfokus pada upaya untuk mengetahui peningkatan kemampuan pemecahan masalah matematis siswa ditinjau berdasarkan pembelajaran dan kemampuan awal matematis (KAM) siswa. Penelitian ini adalah penelitian kuasi eksperimen dengan populasi adalah seluruh siswa kelas X salah satu SMK Swasta di Sumedang. Sampel diambil dua kelas dari sebelas kelas $X$ secara purposive. Sampel yang terlibat sebanyak 64 siswa, 31 siswa kelas eksperimen dan 33 siswa kelas kontrol. Instrumen yang digunakan dalam penelitian ini meliputi tes kemampuan pemecahan masalah matematis. Analisis data menggunakan uji t, uji Mann-WhitneyU, dan uji ANOVA dua jalur dengan interaksi. Berdasarkan hasil analisis data diperoleh kesimpulan: (1) secara keseluruhan dan tiap kategori KAM, tidak terdapat perbedaan peningkatan kemampuan pemecahan masalah matematis antara siswa yang belajar dengan PBM dan ekspositori; (2) tidak terdapat interaksi antara faktor pembelajaran dan faktor KAM terhadap pencapaian kemampuan pemecahan masalah matematis siswa.
\end{abstract}

Kata kunci: pembelajaran berbasis masalah (PBM), pemecahan masalah matematis.

\section{A. PENDAHULUAN}

Dalam Undang-Undang Nomor 20 tahun 2003 tentang Sistem Pendidkan Nasional, Bab I Pasal 1 ayat (1) dikemukakan bahwa pendidikan adalah usaha sadar dan terencana untuk mewujudkan suasana belajar dan proses pembelajaran agar peserta didik secara aktif mengembangkan potensi diri, kepribadian, kecerdasan, akhlak mulia, serta keterampilan yang diperlukan dirinya, masyarakat, bangsa dan negara. Tetapi dalam kenyataannya, diakui bahwa kritik-kritik sering muncul tentang sistem pendidikan yang sering berubah dan tidak seimbang, kurikulum yang kurang tepat dengan mata pelajaran yang terlalu banyak dan tidak berfokus pada halhal yang seharusnya diberikan, dan lain sebagainya (Tayibnapis, 2008: 1). Mengenai kurikulum pendidikan, khususnya di Indonesia terus dikaji dan diperbaharui demi tercapainya tujuan pendidikan sehingga dapat menghasilkan sumber daya manusia yang memiliki keahlian yang tinggi dalam berbagai bidang, termasuk bidang matematika.

Berdasarkan Kurikulum 2013 yang saat ini sedang berjalan, diharapkan pendidikan di Indonesia akan lebih meningkat. Tidak hanya meningkatkan kualitas hasil belajar tetapi kualitas proses belajar siswa. Kemendikbud (2014: 4) menyatakan bahwa Kurikulum 2013 dikembangkan berbasis pada kompetensi yang sangat diperlukan sebagai instrumen untuk mengarahkan peserta didik menjadi: (1) manusia berkualitas yang mampu dan proaktif 
menjawab tantangan zaman yang selalu berubah; (2) manusia terdidik yang beriman dan bertakwa kepada Tuhan Yang Maha Esa, berakhlak mulia, sehat, berilmu, cakap, kreatif, mandiri; dan (3) warga Negara yang demokratis, bertanggung jawab.

Kompetensi yang diharapkan muncul dalam Kurikulum 2013 mencakup kompetensi kognitif, afektif dan psikomotor. Sejalan dengan hal di atas, menurut NCTM (2000), kompetensi yang harus dimiliki siswa dan ditumbuhkan melalui pembelajaran, khususnya dalam pembelajaran matematika adalah kemampuan Problem Solving, Connection, Communication, Reasoning and Proof, and Representation.

Hal serupa diungkapkan oleh Sumarmo (2013: 4), bahwa kemampuan dasar matematika tersebut dapat diklasifikasikan dalam lima jenis yaitu kemampuan: (1) mengenal, memahami dan menerapkan konsep, prosedur, prinsip dan idea matematika, (2) menyelesaikan masalah matematik (mathematical problem solving), (3) bernalar matematik (mathematical reasoning), (4) melakukan koneksi matematik (mathematical connection), dan (5) komunikasi matematik (mathematical communication).

Diberikannya matematika di sekolah tidak hanya membelajarkan siswa agar menguasai pengetahuan dan keterampilan matematis saja, tetapi lebih dari itu matematika sekolah harus dapat mengembangkan kemampuankemampuan tersebut. Beberapa diantaranya yang menjadi perhatian peneliti yaitu kemampuan pemecahan masalah matematis.

Menurut Sumarmo (2013: 348), pemecahan masalah merupakan kemampuan matematis yang meliputi:

a. mengidentifikasi kecukupan data untuk memecahkan masalah;

b. membuat model matematika dari suatu masalah dan menyelesaikannya;

c. memilih dan menerapkan strategi untuk menyelesaikan masalah matematika dan atau di luar matematika;

d. menjelaskan atau menginterpretasikan hasil sesuai permasalahan asal, serta memeriksa kebenaran hasil atau jawaban;

e. menerapkan matematika secara bermakna.

Secara umum, pemecahan masalah bersifat tidak rutin. Oleh karena itu kemampuan ini tergolong pada kemampuan berpikir matematik tingkat tinggi. Dalam penelitian ini, indikator kemampuan pemecahan masalah yang akan diukur adalah kemampuan memahami masalah: kemampuan mengidentifikasi unsur-unsur yang diketahui, ditanyakan dan kecukupan unsur yang diperlukan, membuat/menyusun model matematika: kemampuan merumuskan masalah sehari-hari ke dalam model matematika, memilih strategi pemecahan, dan menjelaskan dan memeriksa kebenaran jawaban.

Pentingnya kemampuan pemecahan masalah matematis tersebut tidak sejalan dengan kenyataan di lapangan,bahwa kemampuan pemecahan masalah matematis siswa pada pembelajaran matematika masih tergolong rendah.

Hal ini didukung oleh hasil penelitian yang dilakukan oleh Putra (2014) pada siswa SMA yang menunjukkan bahwarataan $\mathrm{N}$-gain kemampuan pemecahan masalah matematis pada kelas eksperimen adalah 0,20 dengan klasifikasi peningkatan rendah dan untuk kelas kontrol sebesar 0,15 dengan 
klasifikasi peningkatan rendah. Hal ini menunjukkan peningkatan kemampuan pemecahan masalah matematis pada kedua kelas masih tergolong rendah. Penelitian tersebut menunjukkan bahwa ada masalah dalam kemampuan pemahaman matematis, khususnya siswa SMK/SMA.

Salah satu faktor penyebab rendahnya kemampuan pemecahan masalah matematis siswa dikarenakan pada proses pembelajaran di kelas, siswa masih belum diarahkan pada sikap produktif yang menuntut siswa untuk lebih aktif dalam kegiatan pembelajaran. Selain itu, proses pembelajaran yang digunakan guru masih dominan menggunakan pembelajaran ekspositori.

Dalam membangun pembelajaran matematika yang efektif, dibutuhkan pendekatan pembelajaran yang mampu mengaktifkan semua siswa. Tugas guru tidak hanya mentransfer ilmu pengetahuan, tidak menjadikan siswa sebagai objek pembelajaran melainkan sebagai subjek pembelajaran, sehingga siswa tidak pasif dan dapat mengembangkan pengetahuan sesuai dengan bidang studi yang dipelajari. Oleh karena itu, guru harus memahami materi yang akan disampaikan kepada siswa serta dapat memilih model pembelajaran yang tepat untuk menyampaikan suatu materi.

Pengajaran matematika yang efektif melibatkan pengajaran yang antara lain belajar untuk memahami, menggunakan problem-solving, maupun rote learning (mempelajari setiap hal di luar kepala). Salah satu dari pengajaran yang menggunakan problem-solving adalah Pembelajaran Berbasis Masalah (PBM).

Permanadan Sumarmo(2007: 118) merumuskan pengertian pembelajaran berbasis masalah sebagai suatu pendekatan pembelajaran yang diawali dengan penyajian masalah yang dirancang dalam konteks yang relevan dengan materi yang akan dipelajari untuk mendorong siswa: memperoleh pengetahuan dan pemahaman konsep, mencapai berpikir kritis, memiliki kemandirian belajar, keterampilan berpartisipasi dalam kerja kelompok, dan kemampuan pemecahan masalah. Dengan demikian secara garisbesar, pada pembelajaran berbasis masalah guru menyajikan kepada siswa masalah yang otentik dan bermakna yang dapat memberikan kemudahan bagi mereka untuk melakukan penyelidikan dan inkuiri.

Berdasarkan uraian tersebut tampak jelas bahwa pembelajaran dengan model PBM dimulai oleh adanya masalah (dapat dimunculkan oleh siswa atau guru), kemudian siswa memperdalam pengetahuannya tentang apa yang mereka telah ketahui dan apa yang mereka perlu ketahui untuk memecahkan masalah tersebut. Siswa dapat memilih masalah yang dianggap menarik untuk dipecahkan sehingga mereka terdorong berperan aktif dalam belajar.

Adapun langkah-langkah atau fase-fase yang ditempuh dalam pembelajaran berbasis masalah seperti yang tercantum dalam Kemendikbud (2014: 85-86) sebagai berikut.

a. Fase 1 : Mengorientasikan peserta didik pada masalah.

b. Fase 2 : Mengorganisasikan peserta didik untuk belajar.

c. Fase 3 : Membantu penyelidikan mandiri dan kelompok.

d. Fase 4 : Mengembangkan dan menyajikan artifak (hasil karya) dan memamerkannya. 
e. Fase 5 : Analisis dan evaluasi proses pemecahan masalah.

Pembelajaran PBM telah dibuktikan lebih efektif daripada pengajaran ekspositori dalam memberikan kesempatan untuk mentransfer pengetahuan dan keterampilan dari kelas ke tempat kerja (Stepien \& Gallager, 1994 dalam Liu, 2005). Pembelajaran PBM memberikan hasil retensi konten long term lebih tinggi daripada pengajaran ekspositori (Norman \& Schmidt, 1992 dalam Liu, 2005). Penelitian menunjukkan bahwa pendekatan PBM dapat meningkatkan keterampilan berpikir kreatif siswa dibandingkan dengan pendekatan belajar ekspositori (Awang \& Ramly, 2008). Pembelajaran PBM memiliki karakteristik: (1) pembelajaran yang berpusat pada siswa, (2) membentuk masalah otentik untuk fokus pada belajar; (3) informasi baru diperoleh melalui belajar secara mandiri, (4) belajar terjadi dalam kelompok kecil, dan (5) guru bertindak sebagai fasilitator (Barrows, 1996 dalam Liu, 2005).

Berdasarkan latar belakang masalah yang telah dikemukakan, tujuan penelitian ini sebagai berikut.

1. Menelaah peningkatan kemampuan pemecahan masalah matematis siswa yang belajar dengan pembelajaran berbasis masalah dan ekspositori jika ditinjau secara (a) keseluruhan dan (b) KAM (tinggi, sedang, rendah) siswa.

2. Menelaah apakah terdapat interaksi antara pembelajaran dan KAM (tinggi, sedang, rendah) siswa terhadap pencapaian kemampuan pemecahan masalah matematis siswa.

\section{B. METODE PENELITIAN}

Penelitian ini dilaksanakan dengan menggunakan metode kuasi eksperimen, karena peneliti menerima keadaan subjek apa adanya tanpa membentuk kelas baru.Dalam penelitian ini menggunakan dua kelompok yang dipilih secara acak. Untuk kelompok pertama yaitu sebagai kelas eksperimen dengan pembelajarannya menggunakan Pembelajaran Berbasis Masalah (PBM) dan kelompok kedua sebagai kelas kontrol atau kelas pembanding dengan pembelajarannya menggunakan model pembelajaran ekspositori.

Desain penelitian yang digunakan adalah nonequivalent control group design (Sugiyono, 2012). Desain ini mirip dengan desain pretest-posttest dalam true experiment, tetapi pengambilan sampelnya tidak dilakukan random. Desain untuk aspek kognitif pada penelitian ini digambarkan sebagai berikut.

Kelas Eksperimen Kelas Kontrol

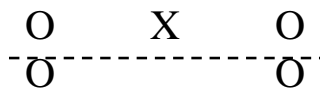

\section{Keterangan:}

$\mathrm{X}$ : pembelajaran berbasis masalah

$\mathrm{O}$ : tes (pretes dan postes kemampuan pemecahan masalah matematis)

--- : pengambilan sampel tidak dilakukan secara random 
Penelitian dilaksanakan pada salah satu Sekolah Menengah Kejuruan (SMK) di Sumedang. Populasi dari penelitian ini adalah seluruh siswa kelas X di salah satu SMK Swasta di Kabupaten Sumedang. Pengambilan sampel dilakukan dengan menggunakan "Purposive Sampling", yaitu teknik pengambilan sampel berdasarkan pertimbangan tertentu (Sugiyono, 2010). Berdasarkan teknik pengampilan sampel tersebut akan diambil sampel dua kelas dari sebelas kelas. Dari pengambilan sampel tersebut, diperoleh kelas X1 dengan jumlah 31 siswa sebagai kelas eksperimen yang menggunakan Pembelajaran Berbasis Masalah (PBM) dan kelas X-8 dengan jumlah 33 siswa sebagai kelas kontrol yang pembelajarannya menggunakan pembelajaran ekspositori.

Penelitian ini menggunakan instrumen tes terdiri dari seperangkat soal tes untuk mengukur kemampuan awal matematis siswa dan kemampuan pemecahan masalah matematis. Tes KAM digunakan untuk mengetahui kesetaraan rerata kelompok eksperimen dan kelompok kontrol dan untuk mengelompokkan siswa berdasarkan kemampuan awal matematikanya. KAM akan diukur melalui seperangkat soal tes materi yang telah dipelajari terutama materi prasyarat untuk mempelajari materi yang akan diberikan dalam penelitian. Berdasarkan perolehan skor KAM, siswa dibagi ke dalam tiga kategori, yaitu KAM kategori tinggi, sedang, dan rendah. Kriteria pengelompokkan KAM siswa sebagai berikut.

a. Jika KAM < 60\% dari skor maksimum ideal maka siswa dikelompokkan ke dalam kategori rendah.

b. Jika $60 \% \leq \mathrm{KAM}<70 \%$ dari skor maksimum ideal maka siswa dikelompokkan ke dalam kategori sedang.

c. Jika $\mathrm{KAM} \geq 70 \%$ dari skor maksimum ideal maka siswa dikelompokkan ke dalam kategori tinggi.

Banyak siswa yang berada pada KAM tinggi, sedang, dan rendah pada setiap kelas disajikan pada Tabel 1 berikut.

Tabel 1

Banyak Siswa Kelompok KAM berdasarkan Kelas PBM dan Ekspositori

\begin{tabular}{|c|c|c|c|}
\hline \multirow{2}{*}{ KAM } & \multicolumn{2}{|c|}{ Kelas } & \multirow{2}{*}{ Total } \\
\cline { 2 - 3 } & PBM & Ekspositori & \\
\hline Tinggi & 6 & 3 & 9 \\
\hline Sedang & 6 & 12 & 18 \\
\hline Rendah & 19 & 18 & 37 \\
\hline Total & 31 & 33 & 64 \\
\hline
\end{tabular}

Adapun instrumen tes kemampuan pemecahan masalah matematis digunakan untuk melihat kemampuan pemecahan masalah matematis siswa dalam menyelesaikan permasalahan-permasalahan matematik. Soal disajikan dalam bentuk uraian, dengan maksud untuk melihat proses pengerjaan yang dilakukan siswa agar dapat diketahui sejauh mana siswa mampu melakukan pemecahan masalah matematis. Soal yang diberikan disusun berdasarkan indikator kemampuan pemecahan masalah matematis. 
Untuk kelancaran penelitian ini dirancang perangkat pembelajaran dan bahan ajar yang dibuat berdasarkan prinsip dan karakteristik model PBM. Perangkat pembelajaran dalam penelitian ini adalah silabus dan Rencana Pelaksanaan Pembelajaran (RPP) untuk 10 kali tatap muka di kelas yang telah disesuaikan dengan kurikulum 2013. Sedangkan bahan ajar yang diperlukan dalam penelitian ini disusun dalam bentuk Lembar Kerja Siswa (LKS).

Teknik pengumpulan dan analisis data diperoleh melalui instrumen berupa tes, yaitu tes kemampuan pemecahan masalah matematis siswa yang digunakan pada saat pretes dan postes.

Uji peningkatan kemampuan pemecahan masalah matematis siswa bertujuan untuk melihat perbedaan peningkatan kemampuan pemecahan masalah matematis siswa antara kelas PBM dan kelas ekspositori. Setelah data yang diperoleh dari hasil pretes dan postes dianalisis, besarnya mutu peningkatan kemampuan pemecahan masalah matematis siswa sebelum dan sesudah pembelajaran dihitung dengan menggunakan rumus gain ternormalisasi (normalize gain), sebagai berikut.

$$
\text { Gain ternormalisasi }(g)=\frac{\text { skor postes-skor pretes }}{\text { skor ideal-skor pretes }}, \quad(\text { Meltzer , 2002) }
$$

Hasil perhitungan gain kemudian diinterpretasikan dengan menggunakan klasifikasi dari Hake (Kesumawati, 2010: 97) yang dapat dilihat pada Tabel 2.berikut.

Tabel 2

Klasifikasi Gain $(g)$

\begin{tabular}{|c|c|}
\hline Skor Gain & Interpretasi \\
\hline$g>0,7$ & Tinggi \\
\hline $0,3<g \leq 0,7$ & Sedang \\
\hline$g \leq 0,3$ & Rendah \\
\hline
\end{tabular}

\section{HASIL PENELITIAN DAN PEMBAHASAN}

Berikut ini adalah sajian statistik deskriptif skor pretes, postes, dan $\mathrm{N}$ gain untuk kemampuan pemecahan masalah matematis.

Tabel 3

Statistik Deskriptif Kemampuan Pemecahan Masalah matematis

\begin{tabular}{|c|c|c|c|c|c|c|c|c|}
\hline \multirow[b]{2}{*}{ Variabel } & \multirow[b]{2}{*}{ KAM } & \multirow[b]{2}{*}{ Data } & \multicolumn{3}{|c|}{ PBM } & \multicolumn{3}{|c|}{ Ekspositori } \\
\hline & & & Pretes & $\begin{array}{c}\text { Postes/ } \\
\text { Post skala }\end{array}$ & $N$-gain & Pretes & $\begin{array}{c}\text { Postes/ } \\
\text { Post skala }\end{array}$ & $\begin{array}{c}N- \\
\text { gain }\end{array}$ \\
\hline \multirow{6}{*}{$\begin{array}{c}\text { Kemampuan } \\
\text { Pemecahan } \\
\text { Masalah } \\
\text { Matematis }\end{array}$} & \multirow{4}{*}{ Tinggi } & $\bar{x}$ & 8,83 & 39,33 & 0,60 & 9,33 & 38,67 & 0,58 \\
\hline & & SD & 3,82 & 7,47 & 0,13 & 1,15 & 4,62 & 0,09 \\
\hline & & $\%$ & 14,72 & 65,56 & & 15,56 & 64,44 & \\
\hline & & $\mathbf{N}$ & \multicolumn{3}{|c|}{6} & \multicolumn{3}{|c|}{3} \\
\hline & \multirow{2}{*}{ Sedang } & $\bar{x}$ & 8,83 & 32,17 & 0,46 & 7,67 & 28,75 & 0,40 \\
\hline & & SD & 1,47 & 8,93 & 0,16 & 0,98 & 7,24 & 0,14 \\
\hline
\end{tabular}




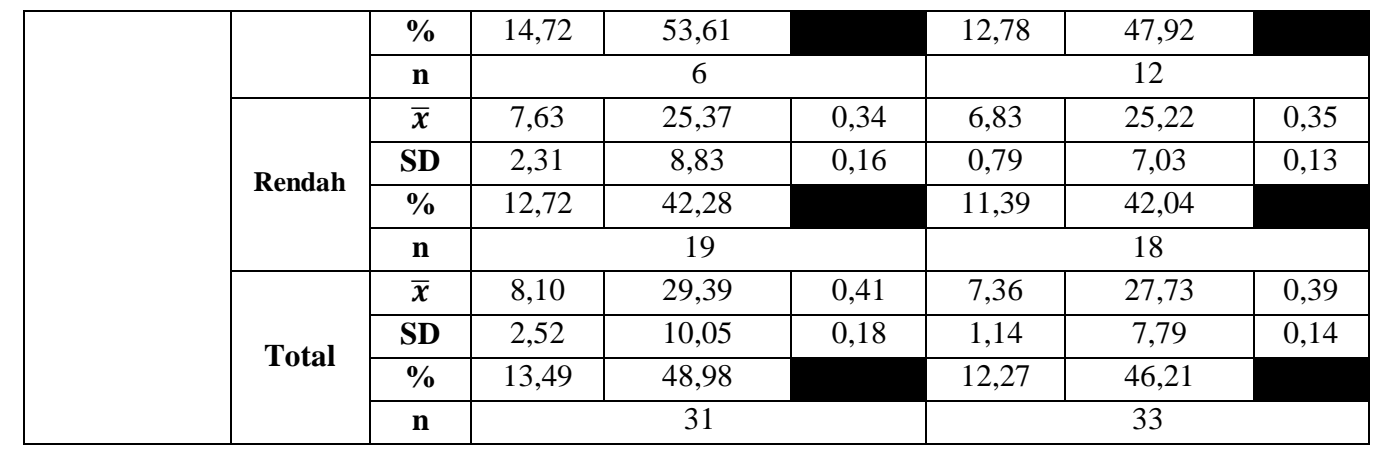

Keterangan:

Skor Maksimal Kemampuan Pemecahan Masalah Matematis $=60$

Analisis skor pretes menggunakan uji perbedaan rataan pretes. Uji perbedaan rataan pretes bertujuan untuk memperlihatkan ada tidaknya perbedaan secara signifikan antara kemampuan pemecahan masalah matematis siswa pada kelas PBM dan ekspositori. Sebelumnya terlebih dahulu dilakukan uji prasyarat normalitas untuk mengetahui skor pretes berdistribusi normal atau tidak.

Uji normalitas skor pretes dihitung dengan uji statistik KolmogorovSmirnov pada taraf signifikansi $\alpha=0,05$ dengan bantuan program SPSS 16 for Windows. Rangkuman hasil perhitungannya disajikan pada Tabel 4berikut.

Tabel 4

Uji Normalitas Skor Pretes Kemampuan Pemecahan Masalah Matematis

\begin{tabular}{|c|c|c|c|c|c|}
\hline \multirow{2}{*}{ Kelas } & \multicolumn{3}{|c|}{ Kolmogorov-Smirnov } & \multirow{2}{*}{ Kesimpulan } & \multirow{2}{*}{ Ket. } \\
\cline { 2 - 4 } & Statistic & Df & Sig. & & \\
\hline PBM & 0,162 & 31 & 0,037 & $\mathrm{H}_{\mathrm{o}}$ ditolak & Tidak Normal \\
\hline Ekspositori & 0,201 & 33 & 0,002 & $\mathrm{H}_{\mathrm{o}}$ ditolak & Tidak Normal \\
\hline
\end{tabular}

$\mathrm{H}_{\mathrm{o}}$ : Data berdistribusi normal

Dari tabel di atas terlihat bahwa skor pretes kemampuan pemecahan masalah matematis siswa kelas PBM dan kelas ekspositori memiliki nilai Sig. $<\alpha(\alpha=0,05)$ sehingga $H_{o}$ ditolak. Hal ini menunjukkan bahwa skor data pretes pada kedua kelas tidak berdistribusi normal. Oleh karena itu tidak perlu dilakukan uji homogenitas melainkan langsung menggunakan uji nonparametrik Mann-Whitney.

Berikut rangkuman hasil uji perbedaan rataan skor pretes.

Tabel 5

Uji Perbedaan Rataan Skor Pretes Kemampuan Pemecahan Masalah Matematis

\begin{tabular}{|c|c|c|c|}
\hline \multicolumn{3}{|c|}{ Statistik } & \multirow{2}{*}{ Keterangan } \\
\cline { 1 - 2 } $\begin{array}{c}\text { Mann-Whitney } \\
\text { U }\end{array}$ & $\mathbf{Z}$ & Asymp. Sig. (2-tailed) & \\
\hline 392,500 & $-1,639$ & 0,101 & $\mathrm{H}_{\mathrm{o}}$ Diterima \\
\hline
\end{tabular}


Dari hasil uji Mann-Whitney $U$ di atas, diperoleh nilai $p$-value atau Sig. (2-tailed) yaitu $0,101>\alpha(\alpha=0,05)$. Hal ini menunjukkan bahwa $\mathrm{H}_{\mathrm{o}}$ diterima, artinya tidak terdapat perbedaan yang signifikan antara skor pretes kemampuan pemecahan masalah matematis siswa kelas PBM dan ekspositori. Dengan kata lain kedua kelas memiliki kemampuan awal pemecahan masalah matematis yang sama sehingga untuk melihat peningkatan kemampuan pemecahan masalah matematis siswa dapat dilihat melalui uji perbedaan skor $N$-gain.

Rataan $N$-gain menggambarkan peningkatan kemampuan pemecahan masalah matematis siswa pada kedua kelas. Rataan $N$-gain kemampuan pemecahan masalah matematis siswa pada kelas PBM dan ekspositori adalah sebesar 0,41 dan 0,39. $N$-gain pada kelas PBM dan ekspositori masuk ke dalam klasifikasi sedang. Berikut rangkuman hasil perhitungan rata-rata dan simpangan baku $\mathrm{N}$-gain kemampuan pemecahan masalah matematis siswa.

Tabel 6

Rekapitulasi $N$-gain Kemampuan Pemecahan Masalah matematis

\begin{tabular}{|c|c|c|c|c|c|}
\hline \multirow{2}{*}{ Kelas } & Data & \multicolumn{3}{|c|}{ KAM } & \multirow{2}{*}{ Seluruh } \\
\cline { 3 - 6 } & Stat. & Tinggi & Sedang & Rendah & \\
\hline \multirow{3}{*}{ PBM } & $\mathrm{N}$ & 6 & 6 & 19 & 31 \\
\cline { 2 - 6 } & $\bar{x}$ & 0,60 & 0,46 & 0,34 & 0,41 \\
\cline { 2 - 6 } & $\mathrm{SD}$ & 0,13 & 0,16 & 0,16 & 0,18 \\
\hline \multirow{3}{*}{ Ekspositori } & $\mathrm{N}$ & 3 & 12 & 18 & 33 \\
\cline { 2 - 6 } & $\bar{x}$ & 0,58 & 0,40 & 0,35 & 0,39 \\
\cline { 2 - 6 } & $\mathrm{SD}$ & 0,09 & 0,14 & 0,13 & 0,14 \\
\hline
\end{tabular}

Berdasarkan Tabel 6 dapat dilihat rata-rata skor $N$-gain siswa kelas PBM lebih tinggi daripada kelas ekspositori. Pada kedua kelas, semakin tinggi kategori KAM semakin besar pula rata-rata skor $\mathrm{N}$-gain siswa.

Untuk mengetahui apakah peningkatan kemampuan pemecahan masalah matematis siswa yang belajar melalui pembelajaran berbasis masalah (kelas eksperimen) lebih baik daripada siswa yang mendapat pembelajaran ekspositori (kelas kontrol), perlu dilakukan pengujian perbedaan rataan skor $N$-gain. Namun sebelumnya harus dilakukan uji prasyarat normalitas dan homogenitas terhadap skor $N$-gain pada kedua kelas.

Untuk menguji normalitas skor $N$-gain dari kemampuan pemecahan masalah matematis digunakan uji kenormalan Kolmogorov-Smirnov pada taraf signifikansi 0,05. Rangkuman hasil perhitungan uji normalitas skor $\mathrm{N}$-gain disajikan pada Tabel 7 berikut.

Tabel 7

Uji Normalitas Skor $N$-gain Kemampuan Pemecahan Masalah matematis

\begin{tabular}{|l|l|c|c|l|l|}
\hline \multirow{2}{*}{ Kelas } & \multicolumn{2}{|c|}{ Kolmogorov-Smirnov } & \multirow{2}{*}{ Kesimpulan } & \multirow{2}{*}{ Keterangan } \\
\cline { 2 - 4 } & Statistic & Df & Sig. & & Normal \\
\hline PBM & 0,127 & 31 & 0,200 & Terima $\mathrm{H}_{\mathrm{o}}$ & Normal \\
\hline Ekspositori & 0,150 & 33 & 0,057 & Terima $\mathrm{H}_{\mathrm{o}}$ & Norinn \\
\hline
\end{tabular}


$\mathrm{H}_{\mathrm{o}}$ : Skor $N$-gain kemampuan pemecahan masalah matematis berdistribusi normal.

Dari Tabel 7 terlihat bahwa nilai signifikansi skor rataan $N$-gain pada kedua kelas lebih dari 0,05 , artinya skor rataan $N$-gain pada kedua kelas berdistribusi normal. Sehingga dilanjutkan ke uji homogenitas.

Uji homogenitas dimaksudkan untuk melihat variansi dari skor $\mathrm{N}$-gain kemampuan pemecahan masalah matematis. Untuk menguji homogenitas digunakan uji Levene dengan taraf signifikansi $\alpha=0,05$. Berikut hasil perhitungan uji homogenitas.

Tabel 8

Uji Homogenitas Skor N-gain Kemampuan Pemecahan Masalah Matematis

\begin{tabular}{|c|c|c|c|c|}
\hline Pembelajaran & $\begin{array}{c}\text { Levene } \\
\text { F }_{\text {hitung }}\end{array}$ & Sig. & Kesimpulan & Ket. \\
\cline { 1 - 5 } PBM & 1,956 & 0,167 & $\mathrm{H}_{\mathrm{o}}$ diterima & Homogen \\
\cline { 1 - 2 } Ekspositori & 1,956 &
\end{tabular}

$\mathrm{H}_{\mathrm{o}}$ : Variansi skor $N$-gain kemampuan pemecahan masalah matematis adalah homogen.

Berdasarkan hasil yang diperlihatkan pada Tabel 8 dapat disimpulkan bahwa skor $\mathrm{N}$-gain pada kelas PBM dan ekspositori untuk kemampuan pemecahan masalah matematis adalah homogen. Hasil analisis terhadap skor $\mathrm{N}$-gain menunjukkan bahwa kedua kelas mempunyai data yang berdistribusi normal dan varians yang homogen. Sehingga untuk pengujian kesamaan skor $N$-gain menggunakan uji statistik parametrik, yaitu Uji-t dengan $\alpha=0,05$. Rumusan hipotesisnya adalah sebagai berikut.

$\mathrm{H}_{\mathrm{o}}: \mu_{\mathrm{E}}=\mu_{\mathrm{K}}$, Tidak terdapat perbedaan rata-rata skor $N$-gain kemampuan pemecahan masalah matematis secara signifikan antara siswa yang belajar dengan PBM dengan siswa yang belajar dengan pembelajaran ekspositori.

$\mathrm{H}_{\mathrm{a}}: \mu_{\mathrm{E}}>\mu_{\mathrm{K}}$, Rata-rata skor $N$-gain kemampuan pemecahan masalah matematis siswa yang belajar dengan PBM lebih baik daripada siswa yang belajar dengan pembelajaran ekspositori.

Rangkuman hasil perhitungan uji perbedaan skor $N$-gain berikut ini.

Tabel 9

Uji Perbedaan Skor $N$-gain Kemampuan Pemecahan Masalah Matematis

\begin{tabular}{|c|c|c|c|c|}
\hline T & df & $\begin{array}{c}\text { Sig. (2- } \\
\text { tailed) }\end{array}$ & $\begin{array}{c}\text { Sig. (1- } \\
\text { tailed) }\end{array}$ & Kesimpulan \\
\hline 0,597 & 62 & 0,552 & 0,276 & Terima $\mathrm{H}_{\mathrm{o}}$ \\
\hline
\end{tabular}

Dari hasil uji-t pada Tabel 9 diperoleh nilai probabilitas $\frac{1}{2}$ sig $(2$-tailed $)=$ 0,276. Nilai ini lebih besar dari taraf signifikansi 0,05 yang ditetapkan, sehingga tidak terdapat perbedaan yang signifikan antara rerata peningkatan 
kemampuan pemecahan masalah matematis siswa kelas PBM dan kelas ekspositori. Hipotesis 1 tidak terbukti.

Untuk mengetahui perbedaan peningkatan kemampuan pemecahan masalah matematis berdasarkan kategori KAM digunakan uji Mann-Whitney $U$ untuk kategori KAM tinggi dan sedang. Hal ini dikarenakan jumlah siswa pada tiap-tiap kategori kecil, sehingga datanya tidak berdistribusi normal. Sedangkan untuk kategori KAM rendah, terlebih dahulu akan diuji normalitas dan homogenitasnya.

Tabel 10

Uji Normalitas Skor $N$-gain Kemampuan Pemecahan Masalah Matematis Kategori KAM Rendah

\begin{tabular}{|c|l|l|l|l|l|l|}
\hline \multirow{2}{*}{ KAM } & \multirow{2}{*}{ Kelas } & \multicolumn{3}{|c|}{ Kolmogorov-Smirnov } & \multirow{2}{*}{ Kesimpulan } & \multirow{2}{*}{ Ket. } \\
\cline { 3 - 7 } & & Statistic & Df & Sig. & & \\
\hline \multirow{2}{*}{ Rendah } & PBM & 0,188 & 19 & 0,077 & Terima $\mathrm{H}_{\mathrm{o}}$ & Normal \\
\cline { 2 - 7 } & Ekspositori & 0,153 & 18 & 0,200 & Terima $\mathrm{H}_{\mathrm{o}}$ & Normal \\
\hline
\end{tabular}

$\mathrm{H}_{\mathrm{o}}$ : Kelompok data berdistribusi normal.

Pada tabel di atas bahwa nilai sig. untuk kedua kelas lebih dari taraf signifikansi 0,05 yang ditetapkan sehingga $\mathrm{H}_{\mathrm{o}}$ diterima. Dengan kata lain, kedua sampel tersebut berasal dari populasi yang berdistribusi normal. Untuk menguji homogenitas varians skor $\mathrm{N}$-gain kemampuan pemecahan masalah matematis kedua kelas dengan kategori KAM rendah dilakukan uji Levene. Ringkasan hasil analisisnya disajikan pada Tabel 11 berikut.

Tabel 11

Uji Homogenitas Skor N-gain Kemampuan Pemecahan Masalah Matematis Kategori KAM Rendah

\begin{tabular}{|c|c|c|c|c|c|}
\hline KAM & Pembelajaran & $\begin{array}{c}\text { Levene } \\
\text { Fhitung }\end{array}$ & Sig. & Kesimpulan & Ket. \\
\hline \multirow{2}{*}{ Rendah } & PBM & \multirow{2}{*}{0,255} & 0,617 & $\mathrm{H}_{\mathrm{o}}$ diterima & Homogen \\
\cline { 2 - 2 } & Ekspositori & &
\end{tabular}

$\mathrm{H}_{\mathrm{o}}$ : Tidak ada perbedaan varians-varians antar kelompok data.

Pada Tabel 11 terlihat bahwa nilai sig. untuk KAM rendah lebih besar dari 0,05 . Hal ini berarti, kategori KAM rendah $\mathrm{H}_{\mathrm{o}}$ diterima atau dengan kata lain variansi skor $\mathrm{N}$-gain kemampuan pemecahan masalah matematis kategori KAM rendah homogen.

Selanjutnya, untuk menguji perbedaan skor $N$-gain pada kategori KAM rendah digunakan uji-t. Kriteria pengujian adalah jika nilai sig. lebih dari $\alpha=$ 0,05, maka hipotesis nol diterima. Rumusan hipotesisnya adalah sebagai berikut.

$\mathrm{H}_{\mathrm{o}}: \mu_{\mathrm{E}}=\mu_{\mathrm{K}}$, Tidak terdapat perbedaan skor $N$-gain kemampuan pemecahan masalah matematis secara signifikan antara siswa kategori KAM tinggi, sedang, dan rendah yang belajar dengan PBM 
dengan siswa kategori KAM tinggi, sedang, dan rendah yang belajar dengan pembelajaran ekspositori.

$\mathrm{H}_{\mathrm{a}}: \mu_{\mathrm{E}}>\mu_{\mathrm{K}}$, Rata-rata skor $N$-gain kemampuan pemecahan masalah matematis siswa kategori KAM tinggi, sedang, dan rendah yang belajar dengan PBM lebih baik daripada siswa kategori KAM tinggi, sedang, dan rendah yang belajar dengan pembelajaran ekspositori.

Tabel 12

Uji Perbedaan Rata-rata Skor N-gain Kemampuan Pemecahan Masalah Matematis Berdasarkan Tiap Kategori KAM

\begin{tabular}{|c|c|c|c|c|c|c|}
\hline KAM & Pembelajaran & $\bar{x}$ & $\begin{array}{c}\text { Uji } \\
\text { Statistik }\end{array}$ & Statistik & $\begin{array}{l}\text { Sig(1- } \\
\text { tailed) }\end{array}$ & Kesimpulan \\
\hline \multirow{2}{*}{ Tinggi } & PBM & 0,60 & \multirow{2}{*}{$\begin{array}{c}\text { Mann- } \\
\text { Whitney } \\
U\end{array}$} & \multirow{2}{*}{7,500} & \multirow{2}{*}{0,3485} & \multirow{2}{*}{$\mathrm{H}_{0}$ diterima } \\
\hline & Ekspositori & 0,58 & & & & \\
\hline \multirow{2}{*}{ Sedang } & PBM & 0,46 & \multirow{2}{*}{$\begin{array}{c}\text { Mann- } \\
\text { Whitney } \\
U\end{array}$} & \multirow[b]{2}{*}{30,500} & \multirow{2}{*}{0,303} & \multirow[b]{2}{*}{$\mathrm{H}_{0}$ diterima } \\
\hline & Ekspositori & 0,40 & & & & \\
\hline \multirow{2}{*}{ Rendah } & $\mathrm{PBM}$ & 0,34 & \multirow{2}{*}{ Uji-t } & \multirow{2}{*}{$-0,138$} & \multirow{2}{*}{0,4455} & \multirow{2}{*}{$\mathrm{H}_{0}$ diterima } \\
\hline & Ekspositori & 0,35 & & & & \\
\hline
\end{tabular}

Berdasarkan Tabel 12 nilai sig. pada tiap kategori KAM untuk kedua kelas (PBM dan ekspositori) lebih dari 0,05. Hal ini menunjukkan bahwa $\mathrm{H}_{\mathrm{o}}$ diterima yang berarti tidak terdapat perbedaan peningkatan kemampuan pemecahan masalah matematis secara signifikan antara siswa kategori KAM tinggi, sedang, dan rendah yang mendapat PBM dengan siswa kategori KAM tinggi, sedang, dan rendah yang mendapat pembelajaran ekspositori. Hipotesis 2, 3 dan 4 tidak terbukti. Hal ini menunjukkan PBM belum berhasil untuk meningkatkan kemampuan pemecahan masalah matematis pada tiap kategori KAM.

Untuk melihat ada tidaknya interaksi antara pembelajaran dan KAM terhadap pencapaian kemampuan pemecahan masalah matematis digunakan uji ANOVA dua jalur. Berikut disajikan hasilnya.

Tabel 13

Hasil Uji ANOVA Dua Jalur

Pencapaian Kemampuan Pemecahan Masalah Matematis

Berdasarkan Pembelajaran dan KAM

\begin{tabular}{|c|c|c|c|c|c|}
\hline Source & $\begin{array}{c}\text { Type III Sum of } \\
\text { Squares }\end{array}$ & $D f$ & Mean Square & $F$ & Sig. \\
\hline KAM $^{1)}$ & 1322,909 & 2 & 661,455 & 10,842 & 0,000 \\
\hline Pembelajaran & 20,845 & 1 & 20,845 & 0,342 & 0,561 \\
\hline KAM $^{*}$ Pembelajaran ${ }^{2)}$ & 30,241 & 2 & 15,120 & 0,248 & 0,781 \\
\hline
\end{tabular}


Dari Tabel 13 hasil ANOVA dua jalur 2) diketahui bahwa nilai signifikansi untuk pembelajaran dan kategori KAM terhadap pencapaian kemampuan pemecahan masalah matematis lebih dari taraf signifikansi ( $\alpha=$ 0,05), yaitu 0,781 maka $\mathrm{H}_{\mathrm{o}}$ diterima, dengan $\mathrm{H}_{\mathrm{o}}$ : tidak terdapat interaksi antara pembelajaran (PBMdan ekspositori) dan KAM (rendah, sedang, dan tinggi) terhadap pencapaian kemampuan pemecahan masalah matematis. Hal ini menunjukkan bahwa pembelajaran dan kategori KAM tidak secara bersama memberikan pengaruh terhadap pencapaian kemampuan pemecahan masalah matematis siswa. Hipotesis 5 terbukti.

Secara grafik, tidak adanya interaksi antara pembelajaran dan KAM dalam peningkatan kemampuan pemecahan masalah matematis dapat dilihat pada gambar berikut.

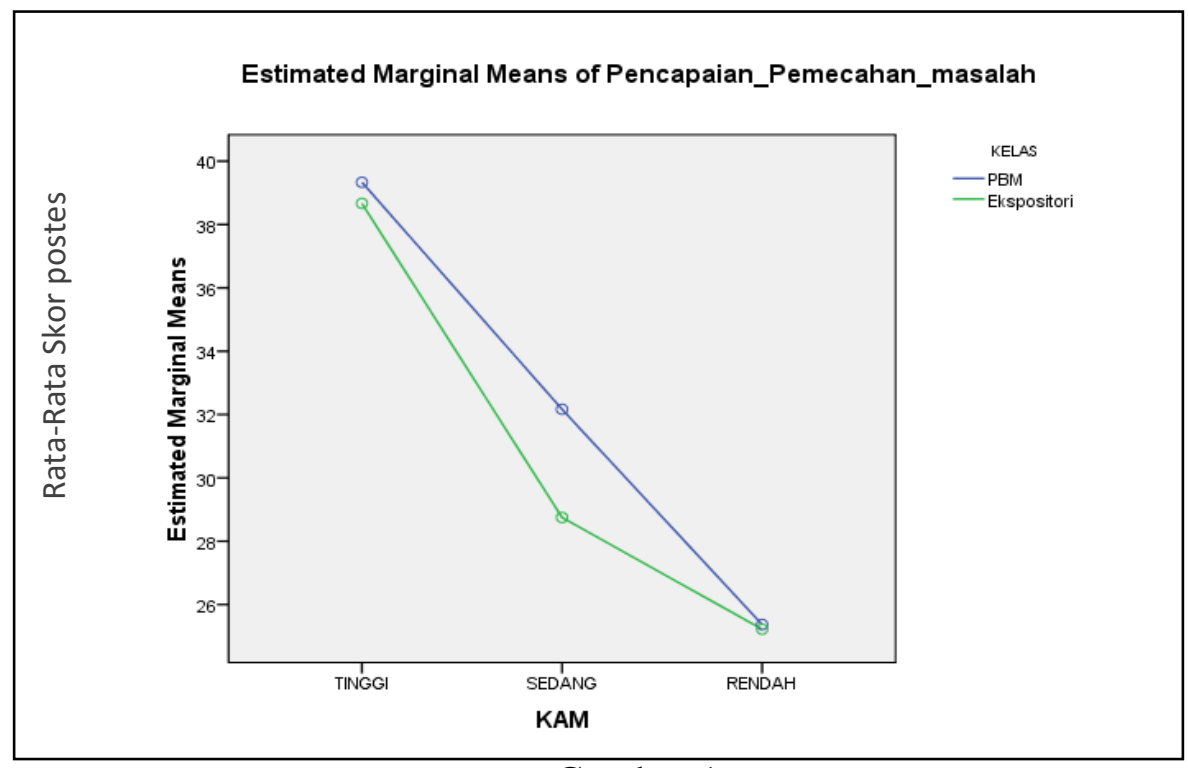

Gambar 1

Interaksi antara Pembelajaran dan KAM terhadap

Pencapaian Kemampuan Pemecahan Masalah Matematis

Dari grafik terlihat bahwa rataan pencapaian kemampuan pemecahan masalah matematis siswa kelas eksperimen yang memperoleh PBM lebih tinggi daripada kelas kontrol yang mendapat pembelajaran ekspositori untuk kategori KAM tinggi dan sedang. Sedangkan untuk kategori KAM rendah, rataan pencapaian kemampuan pemecahan masalah matematis siswa kelas eksperimen yang memperoleh PBM sama dengan kelas kontrol yang mendapat pembelajaran ekspositori.

\section{PEMBAHASAN}

Pada hasil penelitian yang telah dilaporkan sebelumnya menyatakan bahwa tidak terdapat perbedaan peningkatan kemampuan pemecahan masalah matematis siswa yang mendapat PBMdengan siswa yang mendapat pembelajaran ekspositori. Adapun rata-rata pencapaian kemampuan pemecahan masalah matematisuntuk kelas yang mendapat PBM adalah 29,39 
dari skor maksimal 60 atau 48,98\%. Sedangkan rata-rata pencapaian kemampuan pemecahan masalah matematis untuk kelas yang mendapat pembelajaran ekspositori adalah 27,73 dari skor maksimal 60 atau 46,21\%. Pencapaian kemampuan pemecahan masalah matematis kedua kelas masih tergolong rendah. Untuk rata-rata peningkatan kemampuan pemecahan masalah matematis kelas PBM sebesar 0,41 sedangkan untuk kelas pembelajaran ekspositori sebesar 0,39. Peningkatan kemampuan pemecahan masalah kedua kelas tergolong sedang.

Dengan melihat rata-rata postes dan $\mathrm{N}$-gain kemampuan pemecahan masalah matematis kedua kelas, kemampuan pemecahan masalah matematis kelas PBM memang lebih tinggi daripada kelas ekspositori. Namun setelah diuji secara statistik, hal tersebut tidak terbukti.

Hambatan yang ditemukan, dikarenakan siswa belum terbiasa menyelesaikan soal-soal yang terdapat pada tes kemampuan pemecahan masalah yang tidak rutin. Sebagian siswa hanya dapat menyelesaikan soal-soal pemecahan masalah yang biasa atau tingkat kesukarannya masih belum tergolong tinggi. Dapat dilihat dari pencapaian kedua kelas yang masih tergolong rendah, sehingga dibutuhkan pembiasaan menyelesaikan soal-soal kemampuan pemecahan masalah matematis tingkat tinggi.

Selain itu penggunaan waktu yang kurang efisien dalam pelaksanaan PBM, menjadi faktor lain yang menyebabkan rendahnya pencapaian dan peningkatan kemampuan pemecahan masalah matematis. Temuan ini mengindikasikan bahwa PBM belum memberikan pengaruh yang signifikan terhadap peningkatan kemampuan pemecahan masalah matematis.

Selanjutnya, jika ditinjau dari pencapaian setiap item soal, terlihat bahwa siswa yang belajar dengan PBM memiliki rerata pencapaian yang cenderung lebih tinggi daripada siswa yang belajar dengan pembelajaran ekspositori untuk soal nomor 1, 2, 3, dan 6. Gambaran rerata skor pencapaian kemampuan pemecahan masalah matematis untuk setiap item soal tersebut tersaji pada Gambar 2.

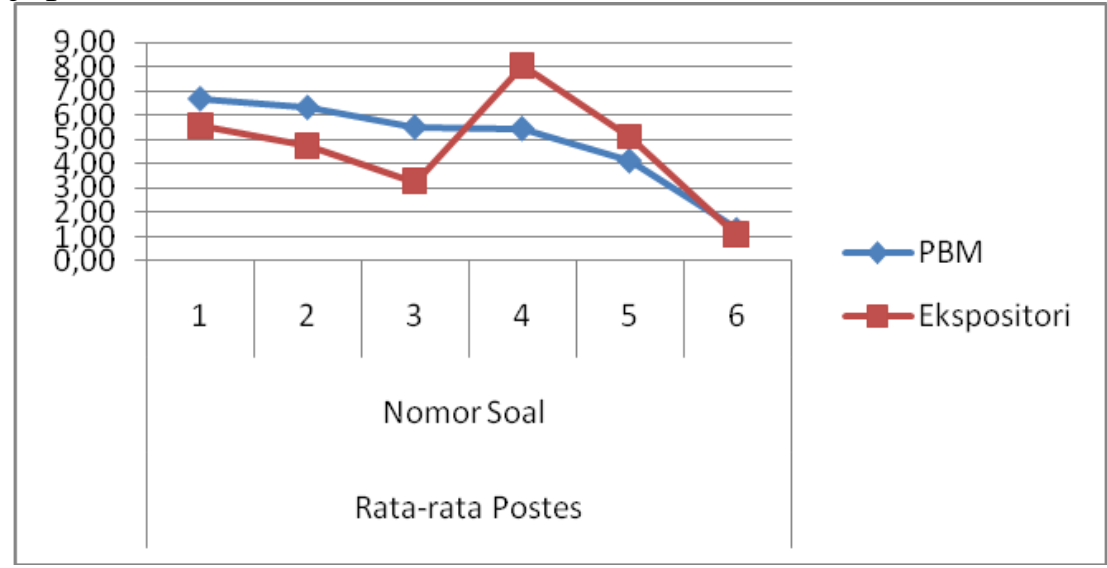

Gambar 2

Rerata Skor Postes Kemampuan Pemecahan Masalah Matematis Setiap Item Soal Ditinjau dari Keseluruhan Siswa 
Telah dijelaskan sebelumnya pada hasil penelitian, bahwa tidak terdapat perbedaan peningkatan kemampuan pemecahan masalah matematis berdasarkan kategori KAM. Sama halnya seperti kendala yang diungkapkan sebelumnya bahwa faktor waktu dan kebiasaan yang menjadi penyebab tidak terdapatnya perbedaan peningkatan kemampuan pemecahan masalah matematis berdasarkan KAM di kedua kelas.

Apabila dilihat dari skor rata-rata $\mathrm{N}$-gain, peningkatan kemampuan pemecahan masalah matematis siswa yang mendapat PBM untuk tiap kategori KAM lebih baik daripada siswa yang mendapat pembelajaran ekspositori. Namun setelah diuji secara statistik, hal tersebut tidak terbukti.

Pada hasil penelitian telah disebutkan bahwa tidak terdapat interaksi antara pembelajaran dan kategori KAM terhadap pencapaian kemampuan pemecahan masalah matematis. Temuan ini menunjukkan bahwa faktor pembelajaran dan KAM tidak secara bersama memberikan pengaruh terhadap pencapaian kemampuan pemecahan masalah matematis siswa.

Dari pemaparan tersebut, dapat ditarik kesimpulan bahwa pencapaian kemampuan pemecahan masalah matematis siswa bisa saja dipengaruhi oleh pembelajaran atau KAM siswa namun tidak secara bersama-sama. Dalam peneltian ini, peran pembelajaran lebih besar daripada peran kondisi awal siswa (kategori KAM) dalam mencapai kemampuan pemecahan masalah matematis.

\section{E. KESIMPULAN}

1. Secara keseluruhan dan tiap kategori KAM,tidak terdapat perbedaan peningkatan kemampuan pemecahan masalah matematis antara siswayang belajar dengan PBM dan ekspositori.

2. Tidak terdapat interaksi antara faktor pembelajaran dan faktor KAM terhadap pencapaian kemampuan pemecahan masalah matematis siswa.

\section{F. DAFTAR PUSTAKA}

Kemendikbud. (2014). Materi Pelatihan Guru Implementasi Kurikulum 2013 Tahun 2014 Mata Pelajaran Matematika SMA/SMK. Jakarta: Pusat Pengembangan Profesi Pendidik BPSDM Dikbud dan Penjaminan Mutu Pendidikan Kementrian Pendidikan dan Kebudayaan.

Kesumawati, Nila. (2010). Peningkatan Kemampuan Pemahaman, Pemecahan Masalah, dan Disposisi Matematis Siswa SMP melalui Pendekatan Pendidikan Matematika Realistik. Disertasi pada PPsUPI Bandung: Tidak diterbitkan.

Liu, Min. (2005). Motivating Students Through Problem-based Learning. Presented at The Annual National Educational Computing Conference (NECC), Philadelphia, PA, June.

Meltzer, D.E. (2002). The Relationship between Mathematics Preparation and Conseptual Learning Gain in Physics.American Journal of Physics. 
[Online]. Tersedia: http://www.physics.edu/per/does/AJP-des-2002Vol.70-1259-1268.pdf. [21 September 2014].

NCTM. (2000). Principle and Standards for School Mathematics. NCTM.

Permana, Y. dan Sumarmo, U. (2007). Mengembangkan Kemampuan Penalaran dan Koneksi Matematik Siswa SMA Melalui Pembelajaran Berbasis Masalah. EDUCATIONIST Vol. I No. 2/Juli 2007.

Putra, R.W.Y. (2014). Penerapan Pembelajaran Konflik Kognitif untuk Meningkatkan Kemampuan Pemecahan Masalah dan Komunikasi Matematis Siswa SMA. Tesis pada PPs UPI Bandung: Tidak diterbitkan.

Sugiyono (2010). Metode Penelitian Pendidikan. Bandung: Alfabeta.

Sugiyono. (2012). Metode Penelitian Kuantitatif dan Kualitatif. Bandung: CV Alfabeta.

Sumarmo, U. (2013). Pembelajaran Keterampilan Membaca Matematika pada Siswa Sekolah Menengah. Dalam Suryadi, D., Turmudi dan Nurlaelah, E. (Penyelia), Kumpulan Makalah Berpikir dan Disposisi Matematik serta Pembelajarannya (hlm. 1 - 24). Bandung: Jurusan Pendidikan Matematika Fakultas Pendidikan MIPA UPI.

Sumarmo, U. (2013). Pendidikan Karakter dan Pengembangan Kemampuan Berpikir dan Disposisi Matematik serta Pembelajarannya. Dalam Suryadi, D., Turmudi dan Nurlaelah, E. (Penyelia), Kumpulan Makalah Berpikir dan Disposisi Matematik serta Pembelajarannya (hlm. 333 375). Bandung: Jurusan Pendidikan Matematika Fakultas Pendidikan MIPA UPI.

Tayibnapis, Farida. Y. (2008). Evaluasi Program dan Instrumen Evaluasi untuk Program Pendidikan dan Penelitian. Jakarta: PT. Rineka Cipta.

Undang-Undang No. 20/2003 tentang Sistem Pendidikan Nasional, Bandung: Fokusmedia. 